\title{
Deliberate and emergent strategies of Lean implementation in Higher Education (HE) - a multiparadigmatic approach.
}

\author{
Justyna Maciąg, Jagiellonian University in Cracow, Poland \\ Justyna.maciag@uj.edu.pl
}

\section{Introduction}

Universities implement the Lean management assuming that it will be as effective as it is in business organizations, despite the fundamentally different nature of HE (Maciąg, 2016; Langer, 2011). Furthermore, in the functionalist paradigm used currently to assess the effects of changes, which is based on superficial "production-oriented" measures, it is impossible to understand fully the essence and mechanism of change in the implementation of Lean. Mintzberg and Waters (1985) emphasize that there is a gap between a deliberate strategy and a planned strategy. Realized strategies are the result of emerged strategies and planned but unrealized strategies. Thus, the following question can be posed: Which strategies are used and which strategies emerge during the implementation of the Lean concept? To answer this, the research perspective should be extended to include a muliparadigmatic approach (Burell and Morgan, 2005; Hatch, 2002; Kostera, 2003; Sułkowski, 2012; Sułkowski, 2016). This will allow an examination of how Lean is perceived in HE institutions and what patterns of behaviour emerge as a result of its implementation. The purpose of this paper is to report on strategies that have been spontaneously emerging in the implementation of Lean management in HE institutions. The paper presents qualitative research on the implementation of the Lean concept in HE institutions worldwide and in Poland.

\section{Theoretical background/Literature review}

Defining and understanding a Lean strategy depends on the adopted paradigm which becomes a unique lens used by the researcher in their observations.

In the light of the functional-systemic paradigm, a Lean strategy is an objective, rational and sequential plan based on data as well as reliable, mainly quantitative, methods of analysis (Sułkowski, 2008). This is a typical top-down intended strategy. Research is dominated by a deductive approach. However, the classical approach to defining and implementing a Lean strategy in universities has many limitations (Langer, 2011; Maciąg 2019; Sułkowski and Lenart-Gansiniec, 2021; Radnor and Bucci 2011; Balzer, 2010; Emiliani, 2015; Antony, 2014; Hines and Lethbridge, 2008; Yorkstone, 2016; Francis et al., 2017; Balzer et al., 2016).

To mitigate the problems resulting from the classical approach to strategy, a model of limited rationality was introduced (Sułkowski, 2008). It is less linear in nature, comprises elements of creativity and initiative, and provides for more fluid planning. Managers create emergent strategies through their everyday experiences (Collis, 2016). Feedback and findings change deliberate strategies. Both deductive and inductive approaches are used in research. It is based on available and selected quantitative and qualitative data.

The introduction of the limited rationality model to the classical model still does not allow a complete and deep cognition and understanding of changes, their mechanism as well as providing them with meaning (Kostera, 2005; Hatch, 2002; Weick, 2016). Therefore, it is proposed to supplement the research perspective with a humanistic approach based on the interpretative-symbolic paradigm (Hatch, 2002; Kostera, 2005; Alvesson, 2009; Czarniawska, 2010; Sułkowski, 2012; Zawadzki, 2014; Weick, 2016). In this approach a strategy is perceived through the lens of its creation and understanding by a social group (Sułkowski, 2008). The approach to reality is intersubjective in nature. A strategy gives meaning to actions of people in 
an organization (Weick, 2016). Planning is first and foremost a source of integration and motivation of employees, a means of rationalizing the unforeseeable future (Sułkowski, 2008). Research on strategy is dominated by an inductive approach based on qualitative data.

Implementing Lean in a university can also be read as oppression, abuse, violence, domination, or something that should not exist at all (Maciąg, 2019). Such an approach falls within the trends of critical management and post-modernism. The rationality of strategy is rejected (Sułkowski, 2008). Employees perceive it as hostile if its elements (values, beliefs, principles, methods) are inconsistent with their expectations (Lenartowicz, 2016). In the organizational dimension, it may be incompatible with a university's organizational culture, which leads to a conflict of values, or a conflict over the Lean principles.

The analysis above shows how differently a Lean strategy can be perceived and examined in the universities and how different patterns of behaviour can emerge in the change process. The conducted review of the literature on the subject indicates that there is a research and publication gap in this area. Therefore, the multiparadigmatic approach offers the possibility of capturing emergent strategies. According to Mintzberg and Waters (1985), what distinguishes emergent strategies from planned strategies is intentions, how they are articulated, whether they can be regarded as organizational and whether actions will be executed in accordance with such intentions. Emergent strategies emerge as unplanned actions that evolve from past experiences or newly identified patterns in the business environment (Bodwell and Chermack, 2010).

\section{Research methodology}

An interpretative paradigm was adopted to the data collection process. In the research, the framework of grounded theory was employed (Charmaz, 2009). In this approach, the concept was generated from empirical data, rather than from existing literature (Charmaz, 2009). The research was qualitative in nature. It was initiated in 2017 and is still ongoing. The adopted research objective, paradigm and procedure allow the project to continue in this way (Creswell, 2013). The research process is inductive, iterative and dynamic. The guiding idea is for the researcher to make the most of the knowledge gained from those working in higher education institutions. Data were and continue to be collected through interviews, observations and analyses of documents in places where people experience the phenomena and issues under examination on a daily basis (universities, meetings within the framework of a community of practice, training courses and workshops). The data used in this paper come from several sources: the international project and the ongoing research at Polish HE institutions.

The main source of data comes from the international project entitled The Conditions for the Maturity of the Lean Management Culture in Higher Education Institutions (the project execution period: 2017 -2018). The author conducted qualitative research using in-depth interviews, observations and analyses of documents at the 5 Polish and the 7 foreign universities (3 universities from the UK, 1 university from Norway, 1 from Canada, 2 from the Netherlands). At the stage of research project preparation, none of the universities in Poland declared having implemented the Lean management concept. Within the framework of the project, the author undertook five days' visits to the universities abroad and carried out 36 interviews. A qualitative analysis of the texts was conducted according to the recommendations formulated in grounded theory by Charmaz (2009).

The results of the international research presented above were supplemented by those obtained from the ongoing observations of the Polish universities. Analysing the research material, the author searched for regularities in reactions to changes. According to the adopted methodology, 
processes, activities and events triggered by the implementation of change were the subject matter of the research (Creswell 2013). The thematic scope of the analysis was based on the research framework established by Mintzberg and Waters (1985). The research material was analysed in the context of the following specific questions:

- Did the strategy have a clear intention/goal and was it planned?

- What was the source of the strategy? As a consequence of what did it emerge?

- Were employees in the organization informed about the strategy? Did they share the common organizational intention/goal?

- Was the strategy implemented as planned? How was it implemented?

In order to obtain answers to the above questions, the author reviewed again the results of the research conducted in the universities abroad. In the second stage of the research, the results of the interview analysis were supplemented by evidence gathered during the interviews, observations and analyses of documents (presentations, notes, research reports) conducted by the author during the research in Poland.

\section{Results/Findings}

Based on diverse sources of materials, the multiparadigmatic research approach presented above allowed the author to look at the strategies of Lean implementation in higher education institutions from a completely new perspective. It showed that the mechanism of Lean strategy development and implementation might not be planned, purposeful, top-down or linear. This became particularly evident when the author juxtaposed the international perspective with the Polish one. The use of the multiparadigmatic approach allowed the author to define and categorize the following five types of strategies:

- a total strategy,

- an advocacy strategy,

- a side-door strategy,

- a virus infection strategy,

- a dripping water strategy.

In a total strategy, a university is treated as a business unit. The Lean concept is introduced with the strong commitment and support of a university's top management, in accordance with the "no exceptions" principle. Conventional leadership evolves strongly towards Lean leadership. The top-down approach is used. Top managers give strong institutional support and LHE is implemented in a conscious and planned manner. This is an intended strategy transformed into a deliberate strategy. A Lean management system is usually well organized and gives support to employees and team leaders. The research indicated that this strategy could be perceived by managers and employees as a forcing strategy. Therefore, ensuring their commitment plays a crucial role in the implementation process. The respondents drew attention that a characteristic feature of many schools was their focus on large, groundbreaking changes or strategic projects, while they were not good at smaller projects related to everyday operations.

An advocacy strategy usually assumes the following form: in a university there is at least one representative of the top management, a Lean enthusiast who promotes, advocates, and supports the concept, ensuring the availability of resources necessary for its implementation. A Lean strategy is negotiated with top managers and is always a form of compromise. It is subsequently developed through a formal and informal network of internal Lean leaders, their training events, projects, and various forms of promotion. This strategy is usually based on one charismatic leader who plays a crucial role in ensuring employees' commitment to changes. If this person were to leave the university, it would constitute a serious threat to all Lean initiatives. A threat 
is also a situation in which, having acquired the consent and legitimacy for their actions, the leader starts to impose their solutions without consulting them first.

A side-door strategy is taken by middle managers in their departments or teams, individual employees holding independent positions and others. They use Lean methods and tools to change processes they own or their places of work. Changes are usually limited to one department, organizational unit or position because of the lack of commitment of other units in a university. It is expected that in time bottom-up activities will force the university top management to change their attitudes. If the Lean idea does not cross organizational borders and win the commitment of the top management, employees could become demotivated and, consequently, start to oppose any change or leave the university.

A virus strategy is an emergent strategy. The essence of this strategy is sharing knowledge, competencies and experiences through informal communication. People start to talk about Lean, refer to it in everyday conversations and even joke about it. This strategy induces interest in Lean among employees, breaks their daily routines and makes their work more sensible and rational. A virus strategy is an inherent part of every Lean strategy, whether it is supported by top managers or not. The awareness of this mechanism is important. This strategy can strengthen activities undertaken under a deliberate strategy or be a meaningful contribution to other strategies. The danger lies in the lack of space in universities for Lean activities, even within an employee's own scope of responsibilities. A person who tries to make changes may be ostracised by other employees because of acting against historically established traditions, disrupting the existing relations, causing ferment, forcing others to reflect on their work or upsetting the status quo. In the future such actions may bring about changes that employees fear.

A strategy of "dripping water" may be used successfully as an auxiliary element in all aforementioned strategies. Dripping water may break a rock and with time changes become irreversible. The author's experience in project execution shows that in principle, after the completion of the first Lean project every person starts to look differently at university processes, wastage, and possibilities of changes. Such a person's way of thinking and attitude change irrevocably. People often reject Lean after the first encounter with the concept, but after some time they start to apply certain solutions and find them useful. This strategy requires time and patience.

The author is aware that HE institutions use a mixed approach to Lean implementation and do it in a more or less intended manner.

\section{Discussion}

In the literature on the subject, a total strategy is the most commonly described approach to the implementation of Lean in HE institutions. Mintzberg and Waters define it as "a planned strategy" (1985). The author's research shows that this approach is dominant in universities based on the Anglo-Saxon and entrepreneurial model, where the academic oligarchy does not have a dominant role in management (in the research, these were foreign universities). It also shows that it could be an effective strategy in the classical sense. It resulted in changing the work culture of every employee. Based on his analysis, Weick points out that successful decentralization must be preceded by the centralization of core values on which an ideology is to be built. Developing a strategy is like creating an ideology. Strong ideologies that contain a harmonious set of values encourage self-control and voluntary cooperation. According to Weick, they can replace formal structures designed to achieve the same objectives (Weick, 2016). In the interpretative approach, the cases of the studied universities showed that the total 
strategy triggered the process of creating bottom-up emergent strategies such as a viral strategy and a dripping water strategy. The author observed that a total strategy could be perceived as a forcing strategy. I could be effect of: numerous fears (Maciąg, 2019; Deal and Kennedy, 1982), a strong sense of autonomy and a dispersion of power, which means that change may not be the result of managerial decisions (Langer, 2011; Maciąg 2019; Sułkowski and Lenart-Gansiniec, 2021), universities' numerous and diverse purposes, which hinders the rationality of assessment and choice of objectives to pursue (Maciąg 2019; Sułkowski and Lenart- Gansiniec, 2021), a strong cultural identity based on tradition (Sułkowski, 2016; Balzer, 2010, Emiliani, 2015), tensions related to the operating model of universities (Geppert and Hollinshead, 2017), frequent institutional isomorphism in change implementation (Santana et al., 2010), institutional political coalitions linked to the electoral cycle that turn plans into games dependent on coalitions, emotions, interests, meanings and symbols (Sułkowski and LenartGansiniec, 2021).

In light of the research conducted by Mintzberg and Waters, an advocacy strategy and a sidedoor strategy are entrepreneurial strategies. Leaders in an organization can realize their visions through operational activities. The condition for such realization is cooperation (Mintzberg and Waters, 1985). The authors stress that this strategy can become a deliberate strategy if other actors, although being critical, have the will to implement it (Collis, 2016). A process of adaptation and negotiation is triggered. It should be remembered that the higher education sector is characterized by status competition and institutional isomorphism (Maciąg, 2019). Therefore, references were made to the universities which are regarded as models worthy of imitation.

In relation to an advocacy strategy, the mechanism for its transformation into a total strategy was observed in universities where the Lean advocate was a member of the university's top management (e.g. chancellor, vice-chancellor). Thanks to their strong political, professional or institutional position, or trust put in them by authorities the advocate obtained the support and resources necessary to implement the Lean concept. This strategy was observed in both foreign and Polish universities. The Sułkowski (2008) mentioned, strategy could be considered as a political process involving the clash of different interest groups and the building of pragmatic coalitions to enhance power. The research did not reveal any case of a side-door strategy being transformed into a total strategy.

If Lean implementation is not accepted by other actors, an advocacy strategy and a side-door strategy become a typical emergent strategies. The author's research shows that an advocacy strategy and a side-door strategy as emergent bottom-up strategies appeared in universities with a strong hierarchical structure, based on a bureaucratic approach and models with a dominant role of the academic oligarchy in management (the Humboldt model). This applies to higher education institutions in Poland. In such universities, the top management was not aware of the need for change or methods of change. Change programmes were initiated by individuals interested in the concept of Lean management (they were members of the management, department heads, team leaders, specialists, consultants, trainers). What also appeared to be important was such persons' belief in the success of their initiatives. A similar mechanism was observed by Mintzberg and Waters (1985). Their research focused on enterprises controlled personally by aggressive owners.

Often, the person initiating change in the university obtained the status of a hero (Deal and Kennedy, 1982) or a change agent (Anvari et al., 2011). Many of the surveyed universities had 
such "heroes" who were responsible for managing the process of change or revealed themselves in this process.

A virus infection strategy and a dripping water strategy can be considered as typical emergent strategies. Their outline emerged during the analysis of data obtained during the research conducted in the universities abroad. The confirmation of such patterns of responding to the Lean concept was found by the author in the analysis of qualitative data from the Polish universities. These strategies emerged in response to actions taken within the framework of Lean implementation in a university or were inspired by participation in conferences, seminars, training events, practitioner network meetings, etc. The irrationality of creating Lean strategies makes it possible for cultural changes to be introduced into universities only through empowerment, denaturalization (challenging the existing status quo) and self-reflection (Lenartowicz, 2016). Author observed that they can also appear as a sign of resistance to the implementation of Lean.

\section{Conclusions}

The research results indicate that the picture of Lean-induced change in universities is very complex. It is a non-linear, ambiguous, relativistic and ideological process. Change may result from a plan or a spontaneous process triggered by factors outside the university. Employees may develop new patterns of acting individually and in groups, even though their university is not officially implementing the Lean concept. Strategies may emerge independently of the university's plan, strengthening or weakening the process. Therefore, going beyond the rationalism adopted in the functionalist paradigm and broadening the research perspective to include an interpretative approach allows a deeper understanding of how change is perceived, attitudes are adopted, and behaviour patterns are created. On the other hand, the international perspective makes it possible to see more clearly the factors that differentiate Lean strategies in different countries and university models. The knowledge of these mechanisms allows us to enrich our understanding of the complexity of implementing Lean management in universities.

\section{Limitations}

All attempts to categorize Lean strategies according to criteria established beforehand have a conventional character and are based on qualitative research methods. The conducted research is of a contributory nature and represents an initial exploration of the topic for the purposes of a wider international research programme.

\section{Acknowledgements}

Results of international study comes from the project entitled The Conditions for the Maturity of the Lean Management Culture in Higher Education Institutions received financing from the MINIATURA 1 programme run by the National Science Centre (the project execution period: 25 September 2017 - 25 September 2018 (no. DEC. - 2017/01/X/HS/00619). 


\section{References}

Alvesson, M. (2009), "At home ethnography: struggling with closeness and closure", in: Ybema,S, Yanow, D., Wels, H., Kamsteeg F. H. (Eds.), Organizational Ethnography: Studying the Complexity of Everyday Life, Sage, London, pp. 156-217.

Antony, J. (2014), "Readiness factors for the Lean Six Sigma journey in the higher education sector", International Journal of Productivity and Performance Management, Vol. 63 No. 2, pp. 257-264.

Anvari, A., Zulkifli, N., Yusuff, R. M., Hojjati, S. M. H., Ismail, Y. (2011), "A proposed dynamic model for a lean roadmap", African Journal of Business Management, Vol. 5 No. 16, pp. 6727-6737.

Balzer, K. (2010), Lean Higher Education, CRP Press, Francis\&Taylor Group, New York.

Balzer, W. K., Francis, D. E., Krehbiel, T. C., Shea, N. (2016), "A review and perspective on Lean in higher education", Quality Assurance in Education, Vol.24 No. 4, pp. 442-462.

Bodwell, W. and Chermack, T. J. (2010), "Organizational ambidexterity: Integrating deliberate and emergent strategy with scenario planning", Technological Forecasting and Social Change, Vol. 77 No. 2, pp. 193-202.

Burrell, G. and Morgan, G. (2005), Sociological paradigms and organisational analysis: Elements of the sociology of corporate life. Ashgale Publishing Company, Ardershot.

Charmaz, K. (2009), Teoria ugruntowana. Praktyczny przewodnik po analizie jakościowej, [Constructing Grounded Theory: A Practical Guide Through Qualitative Analysis], WN PWN, Warszawa.

Collis, D. (2016), "Lean strategy", Harvard Business Review, Vol. 94 No. 3, pp. 62-68.

Creswell, J. W. (2013), Projektowanie badań naukowych: metody jakościowe, ilościowe $i$ mieszane, [Research Design: Qualitative, Quantitative, and Mixed Methods Approaches.] Wydawnictwo Uniwersytetu Jagiellońskiego, Kraków.

Czarniawska, B. (2010), Trochę inna teoria organizacji. Organizowanie jako konstrukcja sieci działań.[A little bit different theory of organization. Organizing as constructing a network of activities.] Poltext, Warszawa.

Deal, T. E. and Kennedy, A. A. (1982), Corporate cultures: The rites and rituals of corporate life, Addison Wesley Publishing Company, Reading.

Emiliani, B. (2015), Lean university: A guide to renewal and prosperity. CLBM, LCC.

Francis D. E., Krehbiel T. C., Balzer W. K. (2017), "Lean Applications in Higher Education", available at: https://the-lmj.com/2017/03/ (accessed 20 March 2017).

Hatch, M. J. (2002), Teoria organizacji, [Organization theory.] WN PWN, Warszawa.

Hines, P., Lethbridge, S. (2008), "New development: Creating a lean university", Public Money and Management, Vol.28 No.1, pp. 53-56.

Kostera, M. (2003), Antropologia organizacji. Metodologia badań terenowych [Anthropology of organizations. Field research methodology.], WN PWN, Warszawa.

Langer, T. (2011), Lean University. The Application of Lean thinking for Improving Processes in Higher Education Institutions: Evidence from three UK case studies, Belfast: Queen's University Belfast, available at: https://standrewslean.com/wpcontent/uploads/sites/83/2016/10/Tobias-Langer-Dissertation.pdf (accessed 29 January 2018).

Lenartowicz, M. (2016). Natura oporu Uniwersytet jako samowytwarzajacy się system spoleczny [The nature of resistance. The university as a self-creating social system.], CSPP UAM, Poznań.

Maciąg, J. (2019), Lean Culture in Higher Education. Towards continuous Improvement. Macmillan Palgrave.

Mintzberg, H., and Waters, J. A. (1985), “Of strategies, deliberate and emergent”. Strategic Management Journal, Vol. 6 No. 3, pp. 257-272. 


\section{$8^{\text {th }}$ INTERNATIONAL CONFERENCE ON LEAN SIX SIGMA}

Radnor, Z., Bucci, G. (2011), Analysis of lean implementation in UK business schools and universities. Association of Business Schools, London.

Sułkowski, Ł. (2008), „Interpretatywny paradygmat strategii organizacyjnej” [An Interpretative Paradigm of Organisational Strategy], in Krupski, R. (Ed.) Zarządzanie Strategicznepodstawowe problemy. Prace Naukowe Wałbrzyskiej Wyższej Szkoły Zarządzania i Przedsiębiorczości, Wałbrzych.

Sułkowski, Ł. and Lenart- Gansiniec, R. (2021), Epistemologia, metodologia i metody badań $w$ naukach o zarządzaniu i jakości [Epistemology, methodology and research methods in management and quality sciences], Wyd. Społeczna Akademia nauk, Łódź.

Sułkowski, Ł. (2012), Kulturowe procesy zarządzania [Cultural management processes.], Difin, Warszawa.

Sułkowski, Ł. (2016), Kultura akademicka. Koniec utopii? [The academic culture. The end of a utopia?], WN PWN, Warszawa.

Weick, K. E. (2016), Tworzenie sensu w organizacjach [Sensemaking in organizations], Wydawnictwo Uniwersytetu Jagiellońskiego, Kraków.

Yorkstone, S. (2016), „Lean universities” in Netland, T., Powell, D. J. (Eds.), The Routledge Companion to Lean Management, Taylor \& Francis (Routledge).

Zawadzki, M. (2014), Nurt krytyczny w zarzadzaniu: kultura, edukacja, teoria [The critical trend in management: culture, education, theory], Wydawnictwo Akademickie SEDNO Spółka Z oo. 